\title{
Comparative Morphometric Study of the Filiform Lingual Pa- pilla in the Middle East Blind Mole Rat (Spalax ehrenbergi, Nehring, 1898) and Wistar Albino Rat
}

\author{
Estudio Morfométrico Comparativo de la Papila Lingual Filiforme en la Rata Topo \\ Ciega del Medio Oriente (Spalax ehrenbergi, Nehring, 1898) y la Rata Albino Wistar
}

Zelal Karakoç'; Sennur Ketani²; M. Aydin Ketani ${ }^{3}$ \& Mehmet Kilinç ${ }^{4}$

KARAKOÇ, Z.; KETANI, S.; KETANI, M.A. \& KILINÇ, M. Comparative morphometric study of the filiform lingual papilla in the Middle East blind mole rat (Spalax ehrenbergi, Nehring, 1898) and wistar albino rat. Int. J. Morphol., 35(2):552-555, 2017.

SUMMARY: This study aimed to reveal the morphometric differences between blind mole rats which live under ground and rats which live under laboratory conditions with regard to the length, base width, keratinization thickness and microscopic papilla depth. For this purpose, 7 adult blind mole rats and 7 adult Wistar albino rats were used in the study. All tongues were removed and fixed in $10 \%$ neutral formalin. 4-5 micrometer of sections were obtained from paraffine sections which were obtained with routine histological follow ups and Crossman's modified triple staining was applied. While papilla length was found as $184.73 \pm 26.68 \mu \mathrm{m}$, base width $65.46 \pm 16.51$ $\mu \mathrm{m}$, keratinization thickness $11.60 \pm 1.37 \mu \mathrm{m}$, microscopic papilla depth $49.89 \pm 8.19 \mu \mathrm{m}$ in blind rats; these values were found as $177.49 \pm 31.44 \mu \mathrm{m}, 50.08 \pm 7.57 \mu \mathrm{m}, 13.08 \pm 5.32 \mu \mathrm{m}$ and $89.12 \pm 19.31 \mu \mathrm{m}$, respectively in rats. While a statistically significant difference was not detected between lengths ( $p>0.05)$, the difference between papilla width was found significant $(p<0.05)$. While keratinization was found to be thicker on posterior side compared to anterior side in both species, a difference was not detected between keratinization thickness measurements ( $>>0.05$ ). The difference between two species with regard to papilla depth was detected to be significant ( $<<0.001)$. The finding that papilla depth decreases as base width increases and the difference's being statistically significant suggested that living in different environments with different humidity could be effective on morphologic structures of the tongue in blind mole rats and rats.

KEY WORDS: Blind Mole Rat; Filiform lingual papilla; Morphometry.

\section{INTRODUCTION}

Tongue is an organ which consists specialized skeletal muscle with different morphologic structures work to catch food, keep them, swallowing and grooming hair (Kılınç et al., 2010a).

An ample amount of macroscopic papillae are present on dorsal side of the tongue. These papillae are defined as filiform, conical, fungiform, foliate and circumvallate papillae. Filiform papillae are the ones with mechanic effect and do not include taste buds, have connective tissue and covering keratinized squamous epithelium. Filiform structures which are conical and cover dorsal side of the tongue help keeping food within the mouth through increasing friction surface (Iwasaki, 2002; Kılınç et al., 2010b).
Tongue plays an important role in feeding together with the intra-oral organs. Tongues of the animals which live in different environments like mammals, poultry, rodents, fish, reptiles, amphibian were analyzed anatomically and histologically under light and electron microscopy in many studies (Kumar et al., 1998; Nishida et al., 2000; Pastor et al., 2008; Nonaka et al., 2008; Harem et al., 2009; Kılınç et al., 2010a; Tütüncü et al., 2012; Reginato et al., 2014; Kuloglu 2016).

Previous studies have reported that keratinization degree and magnitude showed significant differences between species and these differences were associated with humidity (Iwasaki). Papillae on the tongue were also

\footnotetext{
${ }^{1}$ Department of Histology and Embryology, Veterinary Medicine Faculty, University of Siirt, Siirt- Turkey.

${ }^{2}$ Department of Biology Education, Ziya Gökalp Education Faculty, University of Dicle, Diyarbakır- Turkey.

${ }^{3}$ Department of Histology and Embryology, Veterinary Medicine Faculty, University of Dicle, Diyarbakır- Turkey.

${ }^{4}$ Department of Anatomy, Veterinary Medicine Faculty, University of Dicle, Diyarbakır- Turkey.
} 
reported to show morphologic differences between species (Iwasaki; Kuloglu, 2009; Kumar, 1998).

Blind rats are the rodents from Spalacidea family which live under ground. Blind rats are fed with the parts of the plants underground (eg. Tuber, onion, rhizome, root). Potato, carrot and onion compose their food store. Wistar albino rats are the rodents from Murinae family and the most frequently used test animals (Ide \& Mulazımoglu, 2012). These animals are raised under laboratory conditions at 20-24 C and $60 \%$ humidity and with food ad libitum. Standard pellet rat food which consisted of 20-22\% pure protein, $2600-2650 \mathrm{kcal} / \mathrm{kg}$ energy, $4-5 \%$ pure fat and 5-7 $\%$ pure cellulose and with 12-16 $\mathrm{mm}$ diameter was used as rat food (Ide \& Mulazımoglu). Filiform lingual papilla has great importance in taking food and keeping it in their mouths.

A few studies have been encountered in literature investigating morphometric characteristics of tongue papillae. However no studies have been found comparing blind rat and rat tongues anatomically and histologically. This study aimed to reveal the morphometric differences between blind rats which live underground and rats which live under laboratory conditions with regard to the length, base width, keratinization thickness and microscopic papilla depth. Obtained findings are suggested to contribute to literature about the influence of living conditions and feeding differences on histological structure of the tongue.

\section{MATERIAL AND METHOD}

The tongues of 7 adult blind mole rats (male and female) were used in this study. The average weight of the animals was approximately 200-220 g. Animals were collected from steppe areas of Diyarbakir region in Turkey. The specimens were handled and treated according to the local Ethical Board guidelines of Dicle University.

Seven (7) adult Wistar albino rats (male and female) were obtained from the Sabahattin Payzin Health Sciences Research and Application Centre of Dicle University. The animals were handled in accordance with the guidelines of
Dicle University on the care and use of animals (DÜHADEK-2005/40).

The animals were sacrificed by an overdose of intramuscular injection of sodium pentothal and their tongues were then immediately removed.

All tongues were removed and fixed in $10 \%$ neutral formalin. 4-5 micrometer of sections were obtained from paraffine sections which were obtained with routine histological follow ups and Crossman's modified triple staining was applied. Morphometric measurements of filiform lingual papilla were done with ocular micrometers using 20 objective magnification. Whether there is a difference with regard to the length, base width, keratinization thickness and microscopic papilla depth were evaluated with Mann Whitney U test in SPSS program.

\section{RESULTS}

Filiform lingual papillae were seen to be present on dorsal surface of the tongue most, their length was seen to increase toward caudal and sharp ends of the papillae were seen to directed toward caudal. Keratin layer on posterior surface of filiform lingual papillae was seen to be thick and the keratin layer on anterior surface was seen to be thinner in both species. Filiform lingual papillae were seen to be located with larger intervals in blind rats compared to rats.

Length, base width, keratinization thickness and microscopic papilla depth of filiform lingual papillae are shown in Figure 1 and 2.

While a statistically significant difference was not detected between blind rats and rats with regard to filiform lingual papilla length ( $>0.05$ ), the difference between papilla width was seen to be statistically significant $(\mathrm{p}<0.05)$. While keratinization was detected to be thicker on posterior side compared to anterior side in both species, no difference was detected when keratinization thickness measurements were compared statistically ( $p>0.05)$. The difference between two species was found statistically significant when microscopic papilla depth was evaluated $(\mathrm{p}<0.001)$ (Table I).

Table I. Changes in the size $(\mu \mathrm{m})$ of the papillae filiform between Blind Mole Rat and Wistar albino Rat.

\begin{tabular}{lcccc}
\hline \multirow{2}{*}{ Species } & \multicolumn{2}{c}{ Measurement sites } & \\
& Papilla length & Papilla base width & Keratinization thickness & Microscopic papilla depth \\
\hline Blind mole rat $^{\mathrm{a}}$ & $184.73 \pm 26.68$ & $65.46 \pm 16.51$ & $11.60 \pm 1.37$ & $49.89 \pm 8.19$ \\
Rat $^{\mathrm{b}}$ & $177.49 \pm 31.44$ & $50.08 \pm 7.57$ & $13.08 \pm 5.32$ & $89.12 \pm 19.31$ \\
\hline
\end{tabular}

$\mathrm{a}, \mathrm{b}$; difference between groups $(\mathrm{p}<0.05)$. 


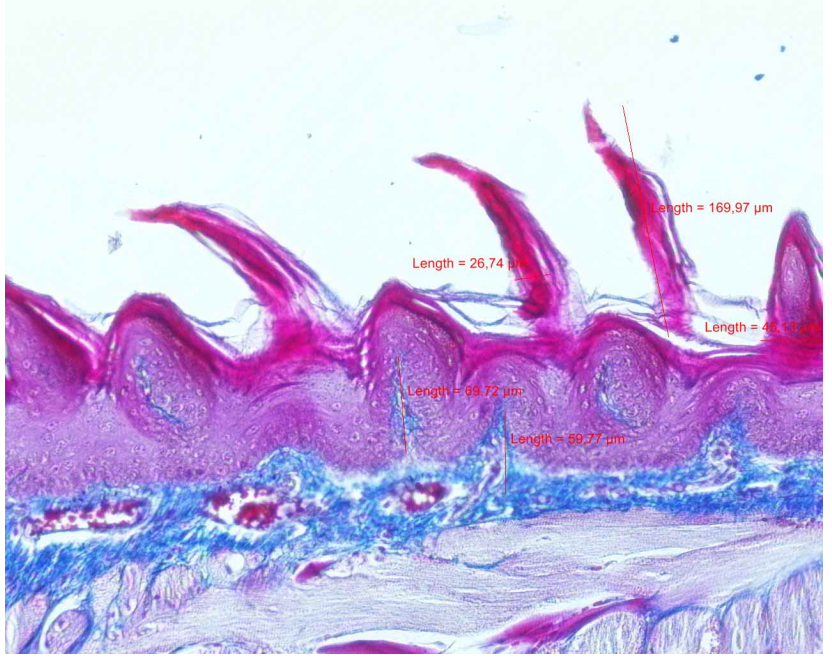

Fig. 1. Measurement sites in blind mole rat (Crossmann's triple $\mathrm{X} 20)$.

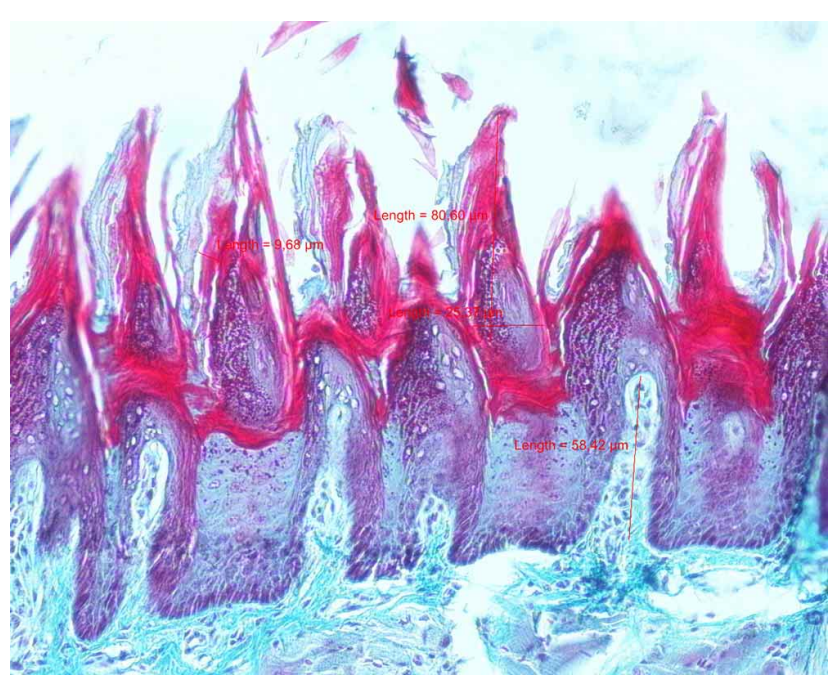

Fig. 2. Measurement sites in rat (Crossmann's triple X20).

\section{DISCUSSION}

Filiform lingual papillae are accepted to have a mechanic function through providing a rough surface proper for movement and grinding of food. Size and shape of filiform lingual papillae differ among species living in different growing environments (Iwasaki; Kuloglu, 2016).

Filiform lingual papillae are as keratinized strand in equidae and also they are thin, long, irregular and high in amount. They are conical, regular and toward caudal in ruminants. They are as two prominences with different size and aligned as a crown toward caudal in carnivores. They are conical and in different lengths in rodents (Kılınç et al., 2010; Nonaka et al., 2008).

Kilınç et al. (2010b) reported that filiform lingual papillae are in strand shape, intensive on dorsal surface of the tongue and in different sizes in different regions of the tongue in their study conducted with blind mole rats. The studies conducted with rats reported that filiform lingual papillae are more abundant on dorsal surface of the tongue however decreased toward caudal (Iwasaki et al., 1997; Kilınç et al., 2010; Reginato et al., 2014). They reported that filiform lingual papillae covered the whole surface of the tongue, directed toward caudal and their length increased toward caudal (Kılınç et al., 2010). The study conducted with rabbits reported that filiform papillae are relatively simple and conical on anterior side including the tip of the tongue and similar with those of rat, mouse, hamster (Nonaka et al., 2008).

This study has revealed that filiform papillae are found more on dorsal surface of the tongue, papilla lengths vary among different regions of the tongue in blind mole rats, and they are more on dorsal surface of the tongue and decreased toward caudal in rats as in various rodent species.

Iwasaki reported that keratinization in tongue varied depending on humidity and increased in drier environments. The present study revealed no significant difference between blind mole rats and rats in different environments with regard to keratinization thickness and localization.

Previous studies reported that papillae on the tongue showed morphologic differences between species in different environments (Iwasaki; Kuloglu, 2016). The present study detected that filiform papillae were localized with larger intervals in blind mole rats compared to rats. This morphologic difference in rats fed with pellet food under laboratory conditions could help mechanic degradation and digestion of food through increasing friction surface.

In this study, length, base width, keratinization and microscopic papilla depth of filiform papillae of blind mole rats and rats were measured with morphometric method and a significant difference was not found between species with regard to length and keratinization thickness ( $p>0.05)$, the difference was found significant between species with regard to base width and microscopic papilla depth $(\mathrm{p}<0.001)$. Papilla length was found as $184.73 \pm 26.68 \mu \mathrm{m}$, base width $65.46 \pm 16.51 \mu \mathrm{m}$, keratinization thickness $11.60 \pm 1.37 \mu \mathrm{m}$, microscopic papilla depth $49.89 \pm 8.19 \mu \mathrm{m}$ in blind mole rats, these values were found as $177.49 \pm 31.44 \mu \mathrm{m}, 50.08 \pm 7.57$ $\mu \mathrm{m}, 13.08 \pm 5.32 \mu \mathrm{m}$ and $89.12 \pm 19.31 \mu \mathrm{m}$, respectively in rats. The finding that papilla depth decreases as base width 
increases and the difference's being statistically significant suggested that living in different environments with different humidity could be effective on morphologic structures of the tongue in blind mole rats and rats.
In conclusion, it may be suggested that morphologic structure of the tongue and specialized structures on the tongue may be influenced from different humidity when blind mole rats which live underground were compared with rats which live under laboratory conditions.

KARAKOÇ, Z.; KETANI, S.; KETANI, M. A. \& KILINÇ, M. Estudio morfométrico comparativo de la papila lingual filiforme en la rata topo ciega del medio oriente (Spalax ehrenbergi, Nehring, 1898) y la rata albino. Int. J. Morphol., 35(2):552-555, 2017.

RESUMEN: Este estudio tuvo como objetivo revelar las diferencias morfométricas de las papilas linguales filiformes entre ratas topo ciegas que viven bajo tierra y ratas que viven en condiciones de laboratorio, con respecto a la longitud, ancho de la base, espesor de la queratinización y profundidad microscópica de las papilas. Para este propósito, se utilizaron 7 ratas topo ciegas adultas y 7 ratas albinas Wistar adultas. Se retiraron las lenguas y se fijaron en formalina neutra al $10 \%$. Se obtuvieron secciones de 4 a $5 \mu \mathrm{m}$ a partir de técnicas histológicas de rutina, aplicándose la tinción triple modificada de Crossman. En las ratas topo ciegas se obtuvieron los siguientes datos morfométricos en relación a las papilas linguales filiformes: longitud 184,73 $\pm 26,68 \mu \mathrm{m}$, ancho de la base 65,46 $\pm 16,51 \mu \mathrm{m}$, espesor de queratinización $11,60 \pm 1,37 \mu \mathrm{m}$, profundidad microscópica de la papila 49,89 $\pm 8,19 \mu \mathrm{m}$, mientras que en las ratas control, los valores que se encontraron fueron 177,49 $\pm 31,44 \mu \mathrm{m}, 50,08 \pm 7,57 \mu \mathrm{m}, 13,08 \pm 5,32 \mu \mathrm{m}$ y $89,12 \pm 19,31 \mu \mathrm{m}$, respectivamente. Si bien no se detectó diferencia estadísticamente significativa entre las longitudes ( $>>0,05)$, la diferencia del ancho de la papila fue significativa ( $\mathrm{p}<0,05$ ). Mientras que la queratinización fue más gruesa en la parte dorsal comparado con la parte ventral en ambas especies, no se detectó diferencia entre las mediciones de espesor de la queratinización (p>0,05). Se detectó que la diferencia entre las dos especies con respecto a la profundidad de la papila era significativa ( $p<0,001)$. Se determinó que la profundidad de la papila disminuye a medida que aumenta el ancho de la base y la diferencia es estadísticamente significativa, lo que sugiere que vivir en diferentes ambientes con diferente humedad podría ser eficaz en las estructuras morfológicas de la lengua de ratas topo ciegas y de ratas de laboratorio.

PALABRAS CLAVE: Rata topo ciega; Papila lingual filiforme; Morfometría.

\section{REFERENCES}

de Souza Reginato, G.; de Sousa Bolina, C.; Watanabe, I. S. \& Polican Ciena, A. Three-dimensional aspects of the lingual papillae and their connective tissue cores in the tongue of rats: A scanning electron microscope study. Sci. World J., 2014: 841879, 2014.

Harem, I. S.; Sari, E. K. \& Kocak, M. Light and scanning electron microscopic structure of dorsal lingual papillae of the Akkaraman sheep. Kocatepe Vet. J., 2(2):8-14, 2009.

Ide, T. \& Mulazimoglu, B. Care and feeding of rats. J. Clin. Anal. Med., 1:45-7, 2012.

Iwasaki, S. Evolution of the structure and function of the vertebrate tongue. J. Anat., 201(1):1-13, 2002.

Iwasaki, S.; Yoshizawa, H. \& Kawahara, I. Study by scanning electron microscopy of the morphogenesis of three types of lingual papilla in the rat. Anat. Rec., 247(4):528-41, 1997.

Kılınç, M.; Erdogan, S.; Ketani, S. \& Ketani, M. A. Morphological study by scanning electron microscopy of the lingual papillae in the Middle East blind mole rat (Spalax ehrenbergi, Nehring, 1898). Anat. Histol. Embryol., 39(6):509-15, 2010b.

Kılınç, M.; Erdogan, S.; Sagsöz, H. \& Ketani, M. A. Is there an effect of sexuality on the morphological characteristic of papillae filiformes in mice. J. Health Sci., 19(1):51-9, 2010a.

Kuloglu, H. Y. Histological development and histochemical structure of partridge (Alectoris chukar) lingual glands at various developmental periods. J. Life Sci., 6(1):205-14, 2016.

Kumar, P.; Kumar, S. \& Singh, Y. Tongue papillae in goat: a scanning electron-microscopic study. Anat. Histol. Embryol., 27(6):355-7, 1998.

Nishida, Y.; Yoshie, S. \& Fujita, T. Oral sensory papillae, chemo- and mechano-receptors, in the snake, Elaphe quadrivirgata. A light and electron microscopic study. Arch. Histol. Cytol., 63(1):55-70, 2000.
Nonaka, K.; Zheng, J. H. \& Kobayashi, K. Comparative morphological study on the lingual papillae and their connective tissue cores in rabbits. Okajimas Folia Anat. Jpn., 85(2):57-66, 2008.

Pastor, J. F.; Barbosa, M. \& De Paz, F. J. Morphological study of the lingual papillae of the giant panda (Ailuropoda melanoleuca) by scanning electron microscopy. J. Anat., 212(2):99-105, 2008.

Tütüncü, A.; Onuk, B. \& Kabak, M. The morphological study of the lingua in stork (Ciconia ciconia). Kafkas Univ. Vet. Fak. Derg., 18(4):623-6, 2012.

\author{
Corresponding author: \\ Zelal Karakoç \\ Department of Histology and Embryology \\ Veterinary Medicine Faculty \\ University of Siirt \\ Siirt \\ TURKEY
}

E-mail: zelalkarakoc@siirt.edu.tr

Received: 29-09-2016

Accepted: 20-01-2017 